\title{
AS ATIVIDADES MODERNAS DA GENÉTICA BOVINA NO BRASIL: FUNÇÕES E LÓGICAS DA ESPECIALIZAÇÃO EM UBERABA (MG)*
}

\author{
LES ACTIVITES MODERNES DE LA GÉNÉTIQUE BOVINE AU BRÉSIL: \\ FONCTIONS ET LÓGIQUES DE LA SPÉCIALISATION À UBERABA (MG)
}

\author{
LAS ACTIVIDADES MODERNAS DE LA GENÉTICA BOVINA EN BRASIL: \\ FUNCIONES Y LÓGICAS DE LA ESPECIALIZACIÓN EN UBERABA (MG)
}

Mirlei Fachini Vicente Pereira - Universidade Federal de Uberlândia - Uberlândia - Minas Gerais - Brasil mirlei@ig.ufu.br

\begin{abstract}
Resumo
Há mais de um século, um conjunto de ações políticas tornaram Uberaba (MG) o principal centro especializado nas modernas atividades de seleção e melhoramento da pecuária bovina brasileira, especialmente no que se refere às raças zebuínas, que hoje correspondem a $80 \%$ do rebanho nacional. Nas últimas décadas, um novo conjunto de agentes e novas atividades modernas se insere no lugar, reforçando o papel de Uberaba como centro da genética bovina no país. No entanto, a coordenação das ações e o volume da produção são em boa parte comandados por um seleto grupo de agentes externos, gerando um controle limitado das atividades do setor. Palavras-chave: pecuária moderna, especialização territorial, globalização, Uberaba.
\end{abstract}

\section{Résumé}

Pour plus d'un siècle, un ensemble d'actions politiques devenue la municipalité de Uberaba (MG) le principal centre d'expertise dans les activités modernes de sélection et d'élevage de bovins au Brésil, en particulier en ce qui concerne les races de zébus, qui représentent aujourd'hui $80 \%$ du cheptel national. Dans les dernières décennies, un nouvel ensemble d'agents et nouvelles activités modernes se mettent en place, renforcement le rôle de Uberaba comme centre de génétique bovine dans le pays. Cependant, la coordination des actions et le volume de la production sont en grande partie contrôlée par un groupe restreint d'agents extérieurs, ce qui donne un contrôle limité des activités du secteur.

Mots clés: bétail moderne, spécialisation territoriale, globalization, Uberaba.

\section{Resumen}

Hace más de un siglo, un conjunto de acciones políticas han convertido Uberaba (MG) en el principal centro especializado en las actividades modernas de selección y mejoramiento de ganado en Brasil, especialmente en lo que respecta a las razas cebuínas, que hoy representan el $80 \%$ del rebaño nacional. En las últimas décadas, un nuevo conjunto de agentes y nuevas actividades modernas son introducidas en el lugar, fortaleciendo del papel de Uberaba como el centro de la genética bovina en el país. Sin embargo, la coordinación de acciones y el volumen de la producción son en gran parte controlados por un grupo selecto de agentes externos, proporcionando un controle limitado de las actividades del sector.

Palabras clave: ganadería moderna, especialización territorial, globalización, Uberaba.

\footnotetext{
* Pesquisa realizada com auxílio financeiro da Fundação de Amparo à Pesquisa do Estado de Minas Gerais FAPEMIG (processo SHA-APQ-04379-10), 2011-2013.
} 


\section{Introdução}

A história do território e de seus usos resulta e é muito marcada pela divisão territorial do trabalho e, consequentemente, pelas funções que os lugares desempenham num conjunto territorial maior, ou seja, na formação socioespacial em que se inserem (Santos, 1977). Assim, a divisão territorial do trabalho é, ao mesmo tempo, a divisão e a repartição dos recursos (materiais e imateriais) mobilizados pelas atividades produtivas e que atuam como "motor", ou vetor determinante, das dinâmicas de uso do território. Em outras palavras, poderíamos afirmar que a história dos lugares é sempre definida por um enredo que se desenha no conjunto do país e hoje, cada vez mais, também pelas funções que desempenham e pelos nexos que estabelecem com o mundo.

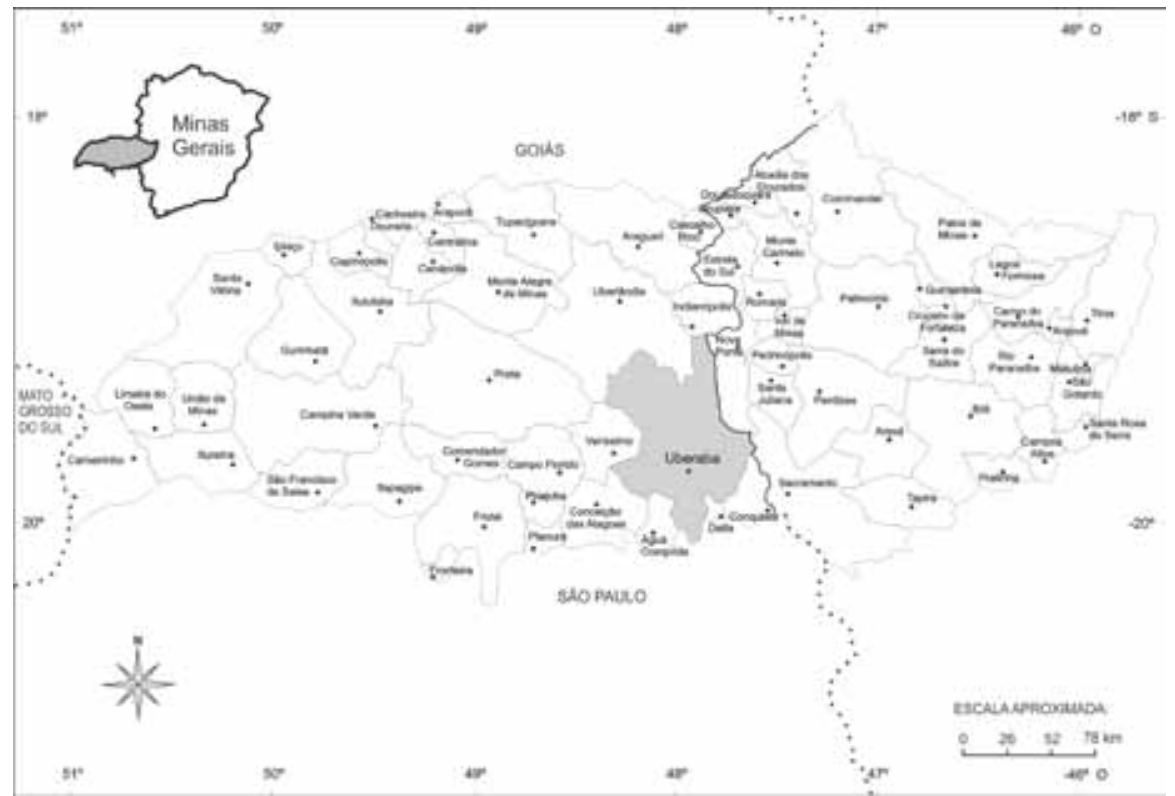

FIGURA 1 - Uberaba e região do Triângulo Mineiro/Alto Paranaíba, Minas Gerais Fonte: Adaptado da base cartográfica de Brito e Lima (2007).

Esse fator condicionante, próprio do desenvolvimento do capitalismo e do progresso contínuo das forças produtivas no território, cria 
condições de especialização e concentração da produção em pontos determinados, que ora desempenham o controle sobre um conjunto de atividades, ora possuem limitado poder de coordenação sobre o trabalho que acolhem.

A formação histórica do território brasileiro é marcada por tais condições, e a situação do município de Uberaba, no estado de Minas Gerais, é emblemática para a compreensão das dinâmicas de especialização dos lugares, em função da divisão territorial do trabalho.

Partindo de tais pressupostos, nossa intenção é avaliar a função de Uberaba como lugar especializado nas modernas atividades que dão suporte à pecuária bovina no Brasil, especialmente os produtos e serviços voltados à genética e à reprodução artificial de animais. E avaliar ainda a natureza de tais atividades e a lógica de sua concentração no lugar, para, posteriormente, arriscarmos uma compreensão da função de Uberaba na coordenação de tais atividades na escala do território nacional, no atual período de globalização.

Gênese e dinâmica de um lugar especializado

A ligação de Uberaba com a atividade de seleção e melhoramento do gado bovino inicia-se no fim do século XIX. Nessa época, o rebanho brasileiro era composto principalmente por raças europeias (gênero bos taurus taurus, comumente denominados taurinos), que em geral eram pouco adaptadas ao meio tropical. A partir da segunda metade do século XIX, criadores fluminenses iniciaram a importação de raças indianas, que se mostraram muito mais adaptadas às características do território brasileiro. Esse gado indiano, que ficou conhecido no Brasil como zebu, integra um conjunto de raças que definem o gênero zebuíno (bos taurus indicus). A adaptabilidade e os ganhos em produtividade dessas raças despertaram grande interesse em alguns criadores nacionais, mas foi no Triângulo Mineiro que um projeto para a difusão do gado indiano ganhou mais força.

Segundo Lopes e Rezende (1984, p. 22-23), os primeiros zebuínos foram introduzidos no Triângulo Mineiro em 1875, adquiridos de criadores do Rio de Janeiro, mas a partir de 1898 pecuaristas de Uberaba e região iniciam a compra de animais diretamente da Índia. Antevendo as possibilidades de melhoria do rebanho nacional com a inserção das raças 
zebuínas, inicia-se em Uberaba um trabalho que organiza a introdução e o registro desses animais no país.

As primeiras décadas do século XX são decisivas para a expansão das raças zebuínas no território nacional. Antes da Primeira Guerra Mundial, o Brasil não atuava na exportação de carnes. O conflito mundial abre mercado para o produto brasileiro e em 1918 o país já exportava mais de 60 mil toneladas de carne (Lopes; Rezende, 1984, p. 31). A expansão da pecuária exigia a inserção da raça mais adaptada às condições do meio tropical, e assim cresce o movimento de importação do gado indiano para melhoramento do rebanho nacional.

Desde os primeiros anos do século XX, Uberaba inicia um conjunto de ações que rapidamente fariam do município o principal centro de difusão das raças zebuínas no Brasil. Em 1906 iniciam-se as exposições do gado zebu, que mais tarde ganharam importância nacional e internacional. Reconhecendo o potencial da exploração econômica das raças, em 1919 é criado em Uberaba um serviço de registro genealógico de animais puro sangue, o herd-book zebu, que emitia atestados de pureza dos animais. Essa atividade foi posteriormente desempenhada pela Sociedade Rural do Triângulo Mineiro (SRTM), criada em 1934, e finalmente pela Associação Brasileira dos Criadores de Zebu (ABCZ), a partir da data de sua criação, em $1967^{1}$ (Lopes; Rezende, 1984). Até hoje a ABCZ é responsável no Brasil pelo registro dos animais zebuínos puros de origem (gado P.O.) e pela organização e realização anual da exposição nacional das raças zebuínas, a Expozebu, hoje a maior feira do gênero no mundo (Figura 2).

A década de 1960 também é marcada pela proibição da importação de bovinos da Índia, ocorrida em 1964. No entanto, estavam dadas as condições para que as atividades de seleção e melhoramento de animais ocorressem a partir do próprio território brasileiro. A ABCZ, fundada e estimulada pela oligarquia rural uberabense, se empenha, com o Estado brasileiro, para a construção de políticas de valorização e defesa de interesses da pecuária nacional. O trabalho de seleção de animais a partir de criadores de Uberaba e de outras partes do país, entre outros aspectos, garantiram a difusão das raças zebuínas no território e o desenvolvimento da pecuária. Em que pese a importação de pouco mais de 6.200 espécimes da Índia até 1962 (Lopes; Rezende, 1984, p. 198), a maior parte do rebanho nacional logo seria composta por animais com sangue zebu, puros 
ou mestiços. Em 2010, cerca de $80 \%$ do rebanho bovino brasileiro era composto por raças zebuínas puras ou mestiças (ABCZ, 2011), sendo a principal delas a Nelore, voltada para a pecuária de corte.

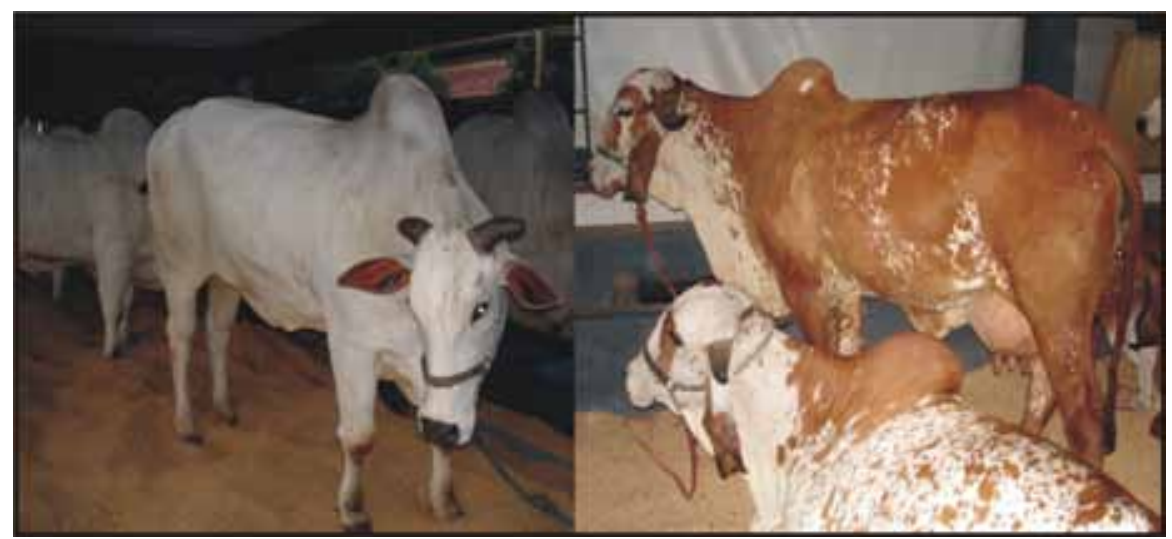

FIGURA 2 - Exemplares zebuínos expostos em Uberaba (MG). A raça Nelore, voltada especialmente para o corte (à esquerda), e a Gir, de aptidão leiteira (à direita), exemplificam algumas das raças de origem indiana. 0 traço mais comum de caracterização das raças zebuínas é a presença do cupim (giba) no dorso, inexistente nas raças de origem europeia.

Fonte: Fotos do autor, 2011.

Mas é a própria dinâmica da atividade pecuária e, portanto, das opções de produção e da função do Brasil na divisão territorial do trabalho, que acaba por fortalecer o papel e a centralidade de Uberaba na coordenação das atividades de registro e difusão da modernização da atividade, mediante o melhoramento de animais. A partir dos anos 1970, a pecuária brasileira conhece um processo de modernização que permitiu que o efetivo do rebanho bovino nacional dobrasse de tamanho entre 1975 e 2010, alcançando hoje mais de 200 milhões de cabeças (IBGE, 2010). Segundo maior produtor mundial, o Brasil detém desde 2004 a primeira posição entre os países exportadores de carne bovina (Lopes et al., 2012).

A partir da década de 1990, a produtividade dos mais eficientes rebanhos comerciais do país dobrou, com a seleção pautada em provas científicas e no uso das técnicas de melhoramento genético. Um animal que há duas décadas atingia peso ideal para abate em cinco anos hoje pode ser abatido na metade do tempo, e mais de $70 \%$ do rebanho nacional já possui traços de melhoramento genético. Para além da precocidade no 
abate, há esforços de seleção e melhoramento genético para que as fêmeas atinjam mais rapidamente a idade reprodutiva (entre 14 e 18 meses), diminuindo o tempo pela metade (Toledo, 2003, p. 29), o que também encurta o ciclo de reprodução do capital investido na atividade. É a nova natureza científica da produção que alcança o campo moderno e redefine a pecuária nacional, tornando-a científica e, ao mesmo tempo, globalizada.

Deste modo, ao trabalho de seleção que utiliza técnicas simples e quase "naturais", realizado em Uberaba há mais de um século, somam-se hoje ciência e informação muito especializadas e capazes de reformular por completo a atividade no lugar, redefinindo suas funções no conjunto do território, ainda que os novos recursos sejam difundidos facilmente apenas entre os produtores mais capitalizados.

Assim, parece-nos que, hoje, a geografia tende a ser cada vez mais uma ciência dos lugares criados ou reformados para atender a determinadas funções, ainda que a forma como os homens se inserem nessa configuração territorial seja ligada, inseparavelmente, à história do presente. (Santos, 1988, p. 52)

Essa é a face formidável do meio técnico - científico informacional (Santos, 1994), redefinindo as possibilidades de produção, ainda que ocorra de forma concentrada e garantindo a acumulação facilitada principalmente aos grandes produtores.

Deste modo, a concentração de tais atividades em Uberaba e a especialização do lugar não ocorrem como mero resultado de uma "localização necessária”, não se dão ao acaso. Elas resultam de ações e processos contextualizados historicamente, que criaram ao longo das últimas décadas demandas para o surgimento de um núcleo especializado em tais atividades e serviços no território brasileiro.

À história do lugar, no que se refere à seleção e ao melhoramento de animais, soma-se um processo, de certo modo recente, de inserção de diferentes agentes que, localizados originalmente em outras partes do país, são atraídos pela "atmosfera” favorável dos negócios da pecuária de elite no município. Isso acaba por criar um deslocamento, ou ao menos a inserção de novas unidades de produção ou oferta de serviços dos grupos que se dedicam a tais atividades no país.

No que tange às atividades de criação, um dos resultados da lógica de concentração e especialização do lugar é a existência em Uberaba de mais de sessenta propriedades de criação de animais de elite (puros de 
origem), especialmente voltados para o melhoramento genético das raças zebuínas (Silva, 2012). Incluem-se, nesse conjunto, criadores e fazendas que há décadas se dedicam à atividade no lugar, bem como grupos de outras regiões de Minas Gerais ou oriundos dos estados de São Paulo, Rio de Janeiro, Mato Grosso do Sul, Goiás, Pernambuco, dentre outros, que se instalam no município principalmente a partir dos anos 1990.

Como a inseminação artificial de bovinos aparece hoje como técnica essencial ao melhoramento dos rebanhos, no que se refere à produção, importação e comercialização de sêmen bovino congelado, Uberaba concentra duas das maiores centrais de produção e comercialização de sêmen do país: a Alta Genetics, empresa canadense instalada no Brasil em 1996, e a ABS Pecplan, que resultou da primeira empresa nacional do ramo, a Pecuária Planejada (Pecplan), fundada em 1970 e hoje controlada pelo grupo inglês Genus. ${ }^{2}$ Outros agentes localizados no município também se dedicam à comercialização de sêmen bovino nacional e importado.

São ofertados em Uberaba produtos de natureza técnico-científica dos mais avançados existentes no mercado mundial, especialmente as modernas técnicas de reprodução artificial de bovinos. Mais de vinte empresas oferecem serviços como os de fertilização in vitro (FIV), produção e comercialização de embriões, transferência de embriões (TE), transferência de embriões em tempo fixo (TETF) e inseminação artificial em tempo fixo (IATF), produção de sêmen sexado (que possibilita a prévia escolha do sexo das progênies), clonagem, exames de DNA etc. A concentração de tais atividades garante mercado também para empresas que fabricam e/ou comercializam equipamentos especializados para as atividades do setor. Assim, a concentração territorial da produção de material genético (sêmen e embriões), bem como outras atividades que lhe dão suporte, definem Uberaba como um lugar muito funcional às atividades do circuito espacial de produção e do círculo de cooperação (Santos, 1986; Santos; Silveira, 2011) da genética bovina no Brasil.

Como a organização e coordenação da informação são ferramentas necessárias ao êxito das atividades modernas, um conjunto de instituições confere ao lugar a centralidade na gestão da informação estratégica à pecuária moderna e, deste modo, Uberaba acaba por concentrar uma parcela importante do círculo de cooperação que dá suporte aos circuitos produtivos da genética bovina e também da moderna pecuária brasileira (carne, leite e derivados). Além da ABCZ e de um conjunto de outras asso- 
ciações específicas das raças zebuínas, Uberaba sedia a Associação Brasileira de Inseminação Artificial (Asbia), instituição fundada em 1974 e que congrega as empresas de produção e distribuição de sêmen bovino e demais materiais ligados à reprodução animal. Uma unidade da Empresa de Pesquisa Agropecuária de Minas Gerais (Epamig), instalada no município na década de 1970, dedica-se especialmente a pesquisas da raça Gir leiteiro. O Polo de Excelência em Genética Bovina, programa de fomento às atividades da genética com recursos do Estado de Minas Gerais, foi instalado na sede da ABCZ em Uberaba em 2009, para otimizar as atividades desenvolvidas no município.

Outros atores acabam por fomentar as atividades e a especialização do lugar também no que se refere à realização e suporte aos negócios da moderna pecuária. São empresas organizadoras de grandes leilões de gado, transmitidos em canais de TV especializados para todo o país, e de consultoria em reprodução e comercialização de bovinos. Mídias dedicadas à difusão da informação do setor e instituições de pesquisa, como é o caso da Epamig, e de ensino, que ofertam cursos nas áreas de Zootecnia e Veterinária, compõem o quadro de atores que cooperam e subsistem no mercado criado pela própria concentração das atividades no lugar.

A BR-050, no trecho próximo à área urbana de Uberaba, pode ser considerada uma verdadeira vitrine das atividades de seleção e criação de animais de elite e dos modernos serviços da pecuária nacional (Toledo, 2003, p. 27). Entre as pouco mais de sessenta propriedades voltadas à seleção e criação de animais de elite existentes no município, trinta localizam-se na BR-050, além das centrais de produção de sêmen, laboratórios veterinários instalados em construções modernas e suntuosas, sofisticados espaços das maiores empresas promotoras de leilões de gado de elite (PO) e dos chamados shoppings de animais, realizados no período dos principais eventos da ABCZ.

É deste modo que a concentração de atividades especializadas possui efeitos econômicos importantes para os lugares, conforme afirma María Laura Silveira (2011, p. 7):

Em primeiro lugar, a acumulação de atividades semelhantes ou complementares numa área cria uma espécie de efeito de massa, uma nova economia de escala que acaba por reduzir os custos globais e individuais. Em segundo lugar, a proximidade entre tais atividades produz um efeito de vizinhança que implica facilitar a difusão de informações gerais e específicas não apenas ligadas aos processos, 
mas interessando também ao próprio funcionamento do mercado, o que representa vantagem comparativa. Esses dois primeiros conjuntos de vantagens criam outros, relacionados à possibilidade de implantação, sustentação e desenvolvimento de serviços especializados locais.

A concentração e a atração dos agentes do setor criam as sinergias necessárias para garantir uma condição favorável à especialização territorial na oferta dos modernos serviços voltados à reprodução artificial de bovinos.

Oferta e natureza dos modernos serviços de reprodução de bovinos

Uma das características expressivas da nova natureza do uso do território, no que se refere às atividades do campo moderno e ao seu caráter globalizado, é a localização e a gestão urbana das atividades que viabilizam a moderna agropecuária nacional. Ao abrigar os nexos do consumo produtivo do campo, a mão de obra especializada e a coordenação e difusão da informação indispensável ao trabalho da agropecuária moderna, o espaço das cidades torna-se o lócus da regulação do campo moderno (Santos, 2008, p. 61).

Em Uberaba, é o espaço urbano que concentra os modernos serviços intensos em técnica e ciência voltados à atividade de melhoramento genético e reprodução de bovinos. A exigência das facilidades de comunicação, a oferta próxima de materiais especializados de uso laboratorial, uma mão de obra qualificada (urbano residente), entre outros aspectos, tornam o meio urbano o ambiente favorável à localização dos agentes. Em que pese a existência de empresas de prestação de serviços ao longo da BR-050 e fora do perímetro urbano, a rodovia, ao menos no que se refere às práticas ligadas à produção, comercialização e oferta de serviços especializados da pecuária, acaba por ganhar uma dinâmica urbana. ${ }^{3}$

Os principais serviços especializados em reprodução de bovinos ofertados em Uberaba são, em síntese, a transferência de embriões in vivo (TE), a aspiração folicular de oócitos (coleta e preparação de óvulos), a produção de embriões a partir de fertilização in vitro (FIV), a clonagem de bovinos, os exames de DNA para avaliar o grau de parentesco dos animais, os serviços de consultoria em reprodução animal etc. Existem ainda empresas que produzem e comercializam instrumentos técnicos 
para a reprodução artificial e outras que comercializam sêmen congelado, embriões e animais vivos. ${ }^{4}$

Muito especializadas e pautadas numa atividade carregada de ciência e informação, tais empresas, ainda que voltadas ao consumo produtivo do campo (Santos, 1994; Elias, 2006) compõem o circuito superior da economia urbana (Santos, 2004), ou seja, são agentes em geral capitalizados, obedientes a normas e ações não geradas exclusivamente a partir do lugar em que se inserem, permitindo a realização das ações modernizantes. Conforme proposta de Milton Santos (2004), esse circuito superior da economia urbana, que inclui os serviços modernos e intensos em capital, resulta diretamente da modernização tecnológica e atua na organização e difusão das novas demandas de consumo e também das modernidades no espaço.

No entanto, temos de reconhecer que as atividades da genética bovina e da reprodução artificial de animais alcançam nos dias atuais também um circuito da economia urbana não essencialmente moderno e organizado e tampouco intenso em tecnologia e informação, como pudemos observar a partir de trabalhos de campo e entrevistas realizadas em empresas. Esse é o caso de alguns agentes que apenas realizam a comercialização de sêmen bovino, atendendo até mesmo clientes de diferentes regiões do país. São normalmente casas agropecuárias, que na região podem ser encontradas em Uberaba e Uberlândia, ou mesmo pequenas empresas especializadas apenas na comercialização de sêmen, que, em geral, atendem os produtores menos capitalizados. Deste modo, podemos reconhecê-los como empreendimentos típicos do circuito superior marginal (Santos, 2004), que cooperam para a distribuição da produção de empresas multinacionais.

Como as grandes centrais de comercialização do produto atendem principalmente os grandes pecuaristas e, por vezes, exigem quantidades mínimas para as compras, a segmentação do mercado consumidor acaba por deixar "sobras", que figuram como nichos de mercado para empresas menores. Assim, a própria especialização dos agentes, bem como a difusão atual das demandas por insumos modernos também entre produtores não muito capitalizados, acaba por multiplicar a divisão do trabalho, ainda que a acumulação no circuito superior seja muito maior.

Entre as características principais das atividades de comércio e serviços voltadas para o melhoramento genético e a reprodução artificial de 
bovinos (que até mesmo denotam seu caráter de circuito superior da economia) podemos identificar as seguintes: a) são atividades de um terciário recente (tanto no lugar como no país); b) têm origem em iniciativas de empresários e capitais locais, mas também têm atraído agentes externos à região e mesmo ao país; c) empregam mão de obra qualificada e por vezes muito especializada (o que requer contratações de fora), que, no entanto, é pouco numerosa; d) demandam insumos (consumo produtivo) não produzidos no lugar e definem um espaço de atuação vasto no território nacional (com clientes em todas as regiões do Brasil).

A concentração de tais serviços e também a sua oferta no território nacional, e particularmente em Uberaba, são recentes. Com exceção do trabalho realizado por uma das primeiras centrais de produção e comercialização de sêmen do país (que data do início dos anos 1970), a oferta de tais serviços especializados e o surgimento de novos agentes que atuam no circuito ocorrem a partir da década de $1990 .{ }^{5}$ Outras grandes centrais de produção e comercialização de insumos instaladas nos anos 1990, somadas à concentração e à inserção de grandes selecionadores de bovinos no município, fornecem as condições para a emergência de um conjunto de agentes que oferecem serviços especializados em reprodução artificial de bovinos, como é o caso de laboratórios veterinários de fertilização in vitro e produção e transferência de embriões.

Se as principais centrais de produção e comercialização de sêmen bovino são hoje comandadas por grupos multinacionais, a maior parte dos laboratórios que oferecem serviços de reprodução artificial de bovinos tem origem local. Tais empresas resultam de capitais locais, em geral oriundas de grupos de empresários que, de algum modo, já participavam da atividade de seleção de bovinos, como tradicionais selecionadores, comerciantes de animais etc. Mas a atmosfera local favorável aos negócios do ramo também foi capaz de atrair recentemente laboratórios de origem externa, tanto internacionais (EUA) como de outros municípios brasileiros, como é o caso de Mogi Mirim (SP), Cravinhos (SP) e Pedro Leopoldo (MG). Situações de complementaridade na oferta de diferentes serviços, estabelecendo solidariedades, sobretudo entre algumas empresas de origem local, convivem, no entanto, com uma acirrada competitividade entre agentes no lugar.

A origem dos empreendimentos de algum modo diferencia também a origem da mão de obra empregada. Se a empresa é multinacional ou tem 
origem em grupos nacionais externos ao município, a mão de obra, principalmente a especializada, é normalmente oriunda de outros lugares. Uma multinacional que atua na produção e comercialização de sêmen, por exemplo, informou-nos que buscou a maior parte de seus funcionários especializados em outras unidades da federação. O mesmo ocorre com laboratórios voltados à prestação de serviços. As empresas de origem local quase sempre empregam mão de obra encontrada em Uberaba, ainda que a formação dos profissionais tenha sido realizada, por vezes, fora do município.

A natureza do trabalho, independentemente da origem ou do porte das empresas, exige principalmente a contratação de profissionais com formação em Veterinária e Zootecnia. Laboratórios que trabalham com clonagem e exames de DNA informaram também o emprego de biólogos e biomédicos. Conforme os dados recolhidos, com exceção das duas maiores centrais que produzem e comercializam sêmen, o efetivo dos empregados nas empresas voltadas aos trabalhos de reprodução artificial e genética bovina varia aproximadamente de dois a vinte funcionários. De algum modo, e pela própria natureza do trabalho, não há grandes oportunidades para a mão de obra não especializada.

Neste período de globalização, quando um lugar se especializa e a oferta de serviços específicos de algum modo concentra-se territorialmente, os fluxos e nexos que sustentam as atividades especializadas se estendem sobre o conjunto do território, ampliando a área de produção, já que se alargam as instâncias de circulação e consumo. Uma vez instalados em Uberaba, os serviços de suporte à pecuária moderna demandam novos fluxos, criando novos nexos territoriais. É a ampliação da vida de relações no lugar, tanto no que diz respeito à produção e aos serviços oferecidos quanto no que se refere ao próprio consumo produtivo das atividades.

Em alguns laboratórios que prestam serviços para a reprodução e melhoramento de bovinos há consumo de fármacos, gases de uso laboratorial adquiridos nos municípios mineiros de Uberaba e Uberlândia ou em Ribeirão Preto (SP), bem como de insumos muito específicos, como botijões de nitrogênio líquido importados dos Estados Unidos ou da França e albumina bovina dos Estados Unidos, insumos normalmente adquiridos em empresas localizadas no estado de São Paulo. As centrais de produção e comercialização de sêmen também definem novos fluxos a partir do lugar. Em que pese a produção de Uberaba ser exportada para 
mais de cinquenta países, conforme nos informou uma das centrais, as empresas também importam esse tipo de material de diferentes partes do mundo, como Estados Unidos, Reino Unido, Nova Zelândia, Canadá, dentre outros países.

Se o consumo produtivo dessas atividades cria fluxos centrípetos, a oferta de tais serviços se estende para a quase totalidade do território nacional. Concentrando informação, organização e tecnologia, tais atividades especializadas alcançam mercados longínquos. A Alta Genetics do Brasil, por exemplo, coordena, a partir de Uberaba, sessenta escritórios de vendas em todas as regiões no país, para onde as mercadorias são distribuídas. Assim, podemos concordar com Santos (1988, p. 51) quando afirma que "quanto maior a inserção da ciência e tecnologia, mais um lugar se especializa, mais aumenta o número, intensidade e qualidade dos fluxos que chegam e saem de uma área”.

As empresas que comercializam sêmen bovino atendem, no mais das vezes, a demandas muito específicas, principalmente de grandes criadores interessados no melhoramento do rebanho. As aquisições são, em geral, também acompanhadas de serviços de consultoria e sempre resultam de um labor técnico-científico que envolve a manipulação de um conjunto significativo de informações (genealogia, características e provas científicas dos animais), cumprimento de normas (sanitárias, de registros etc.) e logística de transporte (terrestre ou aéreo).

Os laboratórios especializados que oferecem serviços de fertilização in vitro, transferência de embriões, clonagem de animais, entre outros, em que pese terem informado que, em geral, a maior parte dos clientes encontra-se em Uberaba ou nas proximidades do município (variando entre $50 \%$ a $70 \%$ do mercado total), atendem clientes em grande parte do território nacional. ${ }^{6}$ Amplia-se deste modo a vida de relações no lugar, ao mesmo tempo que Uberaba torna sua atuação mais espessa e com um maior alcance, afirmando sua função na oferta de serviços especializados nos circuitos da moderna pecuária nacional.

Mas o poder e o alcance das ações são muito desiguais entre os agentes, e se a atuação dos grupos estrangeiros é a que produz os movimentos mais distantes e espessos, o controle e a determinação de tais ações também são coordenados por interesses longínquos. 


\section{Agentes externos e coordenação das atividades}

A avaliação da especialização e da concentração das atividades ligadas à reprodução de animais e à genética bovina em Uberaba restaria incompleta se não atentássemos para o fato de que tais atividades são hoje, em boa parte, comandadas por empresas estrangeiras (grandes multinacionais), que atuam, portanto, como agentes globais, muito obedientes às lógicas e determinações exógenas. De algum modo, para tais agentes, o trabalho de seleção e melhoramento de bovinos, historicamente constituído no lugar, sem dúvida alguma figura como um "recurso territorial" estratégico.

A situação de comando por agentes externos foi definida na década de 1990. Antes disso, já era fato a dependência do país da técnica e dos instrumentos que dão suporte à reprodução artificial de bovinos. ${ }^{7}$ Por isso, há uma inserção ainda restrita (e cara) das atividades em Uberaba com a empresa Pecplan, que foi a pioneira na comercialização de sêmen bovino no Brasil, difundindo comercialmente a técnica de inseminação artificial no país desde 1970. Mas em 1996 a Pecplan foi adquirida pelo grupo estadunidense ABS, que, por sua vez, foi posteriormente incorporado ao grupo Genus, de capital inglês e um dos gigantes do setor, com atuação em mais de cinquenta países. O ano de 1996 é também marcado pela instalação em Porto Alegre (RS) da multinacional canadense Alta Genetics. No ano seguinte, a empresa transfere a sede da filial latino-americana e todas as suas atividades para Uberaba, "localização ótima" para qualquer empresa do ramo. Hoje a Alta Genetics é a maior empresa em venda de sêmen no Brasil, tendo vendido em 2011 mais de 3 milhões do total de 11,9 milhões de doses comercializadas no país.

Em que pese o Brasil ser hoje um dos maiores produtores e exportadores de material genético bovino (sêmen e embriões) (Lopes et al., 2012, p. 31), o volume de importações (principalmente genética leiteira) é ainda muito maior do que o material exportado (genética zebuína voltada para corte). Tal situação aparece claramente nos dados recentes referentes à importação e exportação da Alta Genetics e da ABS Pecplan no Brasil. Segundo dados do Ministério do Desenvolvimento, Indústria e Comércio Exterior (MDIC), ${ }^{8}$ em 2011 a produção exportada pela Alta Genetics do Brasil, principalmente de sêmen bovino, alcançou uma cifra de US\$ 330,4 mil, enquanto o material importado da mesma natureza alcançou a quan- 
tia de US\$ 7,5 milhões. Outra empresa localizada em Uberaba e especializada apenas na comercialização de sêmen importado da Nova Zelândia, a NZ Brasil, importou cerca de US\$ 190 mil em material genético.

A inserção facilitada do produto importado no Brasil também é realizada pela ABS Pecplan. Ainda segundo dados do MDIC, a ABS Pecplan do Brasil exportou, também no ano de 2011, US\$ 269,4 mil em material genético bovino. Em contrapartida, as importações realizadas nesse ano pela ABS Pecplan somaram mais de US\$ 6,4 milhões. Localizada em área do município de Delta (MG), as importações dessa empresa representam a quase totalidade das importações realizadas no município (mais de 98\%). O laboratório Goyaike Agropecuária, que presta serviços à ABS Pecplan e funciona junto às instalações da empresa, realizou o restante das importações do município no mesmo ano.

A Nova Índia Genética, empresa de capital nacional instalada em Uberaba nos anos 1990, que já foi uma das principais centrais de produção e comercialização de sêmen bovino, não consegue fazer frente às gigantes multinacionais do setor instaladas no país, que com facilidade importam e exportam material genético a partir de suas bases de produção no exterior. Por isso, vem perdendo participação no mercado, atuando basicamente na oferta de serviços de coleta e congelamento de sêmen.

Deste modo, se o lugar controla as informações referentes ao registro dos animais de elite (por meio da ABCZ), as atividades de comercialização, exportação e importação de material genético são controladas por grandes grupos multinacionais, os que mais lucram e acumulam com a exploração dessas atividades.

\section{Considerações finais}

Entre as transformações operadas nas últimas décadas pela dinâmica e expansão da moderna agropecuária no Brasil, a emergência de lugares especializados, onde se concentram os modernos serviços que dão suporte às atividades produtivas na escala do território nacional, constitui uma das situações geográficas mais significativas. A condição de Uberaba como centro especializado das atividades que envolvem a genética e a reprodução bovina resulta desse processo e exemplifica tal situação.

Em decorrência dos esforços de criadores locais e de um processo histórico que remonta ao fim do século XIX (com a presença de grandes 
selecionadores, a criação e a forte atuação da ABCZ no conjunto do território nacional etc.), hoje a economia de aglomeração das atividades voltadas à genética e reprodução artificial de bovinos em Uberaba é, de certo modo, muito funcional às demandas técnico-científicas da pecuária moderna e competitiva que se instala no Brasil nas últimas décadas. E ainda há um imenso potencial de crescimento, já que apenas cerca de $10 \%$ do rebanho comercial do país é inseminado (Lopes et al., 2012). Algumas grandes centrais de produção e comercialização de material genético bovino, bem como um conjunto bem mais vasto de agentes voltados à prestação de serviços de reprodução animal, fabricação e venda de insumos e equipamentos especializados etc., acabam por reforçar e tornar mais ampla a função de Uberaba como centro de difusão de tais modernidades no território nacional.

A organização política dos pecuaristas, o ordenamento e a difusão da informação técnico-científica, essenciais a tais circuitos produtivos, e a articulação e inserção no mercado das tecnologias resultantes das pesquisas realizadas em território nacional e no exterior ${ }^{9}$ revelam uma dimensão importante do círculo de cooperação que se realiza a partir do município, indissociável da produção dos circuitos produtivos da genética bovina e também da pecuária. Assim, no lugar se encontram e se superpõem atividades importantes dos circuitos espaciais de produção e dos círculos de cooperação da genética bovina e da pecuária nacional em suas faces mais modernas, além de uma concentração do trabalho especializado, que também é compartilhado por empresas de natureza e poder de atuação muito diferentes.

Observando a inserção e o controle das atividades por grandes empresas multinacionais, encontramos em Uberaba uma situação que revela, no lugar, a face geográfica da globalização. Servindo de localização estratégica para algumas das maiores empresas multinacionais que detêm o oligopólio do negócio milionário da comercialização de material genético bovino no Brasil, Uberaba acaba por servir de "plataforma" de atuação e ponto de inserção desses agentes no territorial nacional. Mais uma vez, são as circunstâncias do período e as estratégias de acumulação das empresas (em sua face geográfica mais direta) que definem a função do lugar no conjunto do país e, de algum modo, também no conjunto do mundo. É assim que a "divisão territorial do trabalho cria uma hierarquia entre lugares e, segundo a sua distribuição espacial, redefine a capacidade 
de agir de pessoas, firmas e instituições” (Santos, 1996, p. 108). Ou seja, a condição de lugar especializado, ainda que tais atividades não envolvam a maior parte da produção e da população, é em boa parte ditada e ritmada pelas funções hegemônicas que cada lugar/região desempenha no conjunto da nação, mesmo que o controle local das atividades seja limitado ou mesmo nulo.

Se as demandas por tais serviços modernos decorrem, de modo direto ou indireto, da globalização e da inserção competitiva da pecuária nacional no mercado externo, podemos dizer que as novas ou renovadas funções de Uberaba, no que se refere à sua centralidade nas ações da pecuária nacional, também resultam da lógica globalizada e da participação do país na divisão internacional do trabalho, como grande exportador de commodities. É, desta forma, um conjunto de ações especializadas com um controle de certo modo limitado, porque dependente de interesses voltados a mercados longínquos e comandados estruturalmente por grupos externos.

Deste modo, experiência e saberes longamente elaborados no lugar (com mais de um século desempenhando as atividades de seleção e melhoramento), justamente quando alcançam um patamar científico-tecnológico moderno, capaz de revolucionar o melhoramento e a produtividade do rebanho nacional com rapidez e a preços mais competitivos, são agora coordenados por agentes externos, que muito concentram as atividades de produção e a comercialização. Uma outra organização, que aproveitasse de forma mais generosa os esforços historicamente produzidos no lugar e especialmente voltada para os interesses de um conjunto maior de agentes no país, seria capaz de reformular as atividades produtivas da pecuária, redistribuindo melhor os recursos.

\section{Notas}

1. No governo ditatorial de Castelo Branco (1964-1967), por força de lei, as sociedades e associações rurais tiveram de ser transformadas em sindicatos. Como a SRTM realizava o registro genealógico e atestava a pureza das raças, convencionou-se que a entidade seria desmembrada em duas instituições: o Sindicato Rural do Triângulo Mineiro e a ABCZ, que se tornou responsável pelo registro dos animais e a realização das exposições (Lopes; Rezende, 1984, p. 111).

2. A ABS Pecplan hoje se encontra localizada em área do município de Delta (MG), por causa do desmembramento territorial para a criação desse municí- 
pio, em 1995. De todo modo, as práticas, a mão de obra e a inserção das atividades da empresa são totalmente voltadas para Uberaba.

3. As características de uma das empresas do ramo parecem significativas dessa situação: localizada na BR-050, a $15 \mathrm{~km}$ do centro de Uberaba, possui 150 funcionários trabalhando na unidade do município, muitos dos quais operando vendas ou contatos internacionais por computadores e telefones, todos eles urbano residentes. A BR-050, que concentra alguns dos serviços especializados no setor, ganha assim uma dinâmica urbana típica e ligada aos negócios modernos.

4. A partir dos levantamentos que realizamos desde o segundo semestre de 2011, encontramos em Uberaba mais de trinta empresas de alguma forma ligadas às atividades que dão suporte à moderna pecuária no Brasil. Entre os laboratórios voltados aos serviços de reprodução e empresas que produzem e/ou comercializam sêmen, embriões ou instrumentos técnicos para reprodução de bovinos, contabilizamos vinte e duas empresas. Quinze delas foram por nós visitadas e seus dirigentes entrevistados durante os meses de maio e junho de 2012.

5. A técnica de produção in vitro de embriões surge nos Estados Unidos em 1982 (Varago et al., 2008). Em uma década, tais procedimentos, que garantem um extraordinário avanço nas atividades de reprodução artificial de bovinos, são inseridos no Brasil e difundidos comercialmente em Uberaba na década de 1990.

6. Avaliando a origem de clientes localizados em outras regióes, entre os estados mais frequentemente citados pelas empresas que prestam tais serviços, conforme levantamos nas entrevistas realizadas, estão: Minas Gerais, São Paulo, Rio de Janeiro, Goiás, Mato Grosso, Pará, Bahia e Pernambuco.

7. As técnicas de inseminação artificial surgem na Europa nos anos 1920, enquanto as técnicas de congelamento de sêmen, TE e FIV, são desenvolvidas nos EUA entre os anos de 1950 e 1980 (Varago et al., 2008, p. 100).

8. É apenas a partir de 2011 que os volumes de importação e exportação realizados nos municípios brasileiros começam a ser informados também a partir das principais empresas importadoras/exportadoras, daí a ausência de uma série histórica de informações. Disponível em: <www.desenvolvimento.gov. br>. Acesso em: jun. 2012.

9. Insistimos na função de Uberaba como centro de oferta e difusão dos serviços especializados porque a produção propriamente dita do conhecimento científico aplicado ao circuito normalmente resulta, ao que nos parece, principalmente dos tradicionais centros de pesquisa localizados, sobretudo, no estado de São Paulo. Instituições voltadas à pesquisa agropecuária que de há longa data funcionam em território paulista ainda hoje concentram parte significativa da produção do conhecimento científico aplicado à pecuária em geral e à genética bovina em particular, como é o caso, por exemplo, do Instituto de Zootecnia do Estado de São Paulo, que atua desde o início do século XX e tem unidades em Nova Odessa e Sertãozinho; da Embrapa Pecuária Sudeste em São Carlos, que desenvolve pesquisas desde a década de 1930; da Universidade de São Paulo - Esalq Piracicaba e mais recentemente também em Pirassununga e Ribeirão Preto; e da Universidade Estadual Paulista, que atua em pesquisas desde os 
anos 1960, em Botucatu e Jaboticabal. Algumas instituições localizadas em Minas Gerais também contribuem com as atividades de pesquisa, como é o caso da Embrapa Gado de Leite, fundada em 1976 em Juiz de Fora, da UFMG e das universidades federais de Lavras e Viçosa.

\section{Referências}

ABCZ. Associação Brasileira dos Criadores de Zebu. Disponível em: <www.abcz. org.br>. Acesso em: nov. 2011.

BARBOSA, R. T.; MACHADO, R. Panorama da inseminação artificial em bovinos. São Carlos: Embrapa Pecuária Sudeste, 2008. (Série Documentos, n. 84).

ELIAS, D. Globalização e fragmentação do espaço agrícola no Brasil. Scripta Nova. Barcelona, v. X, n. 218 (3), 19 p., 2003.

IBGE - Instituto Brasileiro de Geografia e Estatística. Censos agropecuários / IBGE-Sidra 2010. Disponível em: <http://www.sidra.ibge.gov.br/>. Acesso: 2012.

LOPES, M. A. B.; REZENDE, E. M. ABCZ: 50 anos de história e estórias. Uberaba, MG: ABCZ, 1984.

LOPES, B. C. et al. Genética bovina brasileira: mercado internacional e mapeamento das competências e tecnologias mineiras. Uberaba, MG: Fapemig, 2012.

SANTOS, M. Société et espace: la formation sociale comme théorie et comme méthode. Cahiers Internationaux de Sociologie, v. LXIII, p. 261-276, Paris, 1977.

SANTOS, M. Circuitos espaciais de produção: um comentário. In: SANTOS, M.; SOUZA, M. A. A. (Ed.). A construção do espaço. São Paulo: Nobel, 1986. p. 121-134.

SANTOS, M. Metamorfoses do espaço habitado. São Paulo: Hucitec, 1988.

SANTOS, M. Técnica, espaço e tempo. Globalização e meio técnico-científicoinformacional. São Paulo: Hucitec, 1994.

SANTOS, M. A natureza do espaço. Técnica e tempo. Razão e emoção. São Paulo: Hucitec, 1996.

SANTOS, M. O espaço dividido. Os dois circuitos da economia urbana nos países subdesenvolvidos. São Paulo: Edusp, 2004 [1. ed. 1975].

SANTOS, M. A urbanização brasileira. São Paulo: Edusp, 2008 [1. ed. 1993].

SANTOS, M.; SILVEIRA, M. L. O Brasil: território e sociedade no início do século XXI. Rio de Janeiro: Record, 2001.

SILVA, L. R. A agropecuária moderna em Uberaba-MG: produção, consumo produtivo e especialização territorial. Relatório Final de Iniciação Científica. CNPq-UFU, 2012.

SILVEIRA, M. L. Território usado: dinâmicas de especialização, dinâmicas de diversidade. Ciência Geográfica, v. XV, n. 1, p. 4-12, Bauru, 2011.

TOLEDO, L. R. A lapidação do zebu. Aprimoramento genético do principal boi brasileiro produz animais precoces, dotados de mais partes nobres e menos 
sujeitos a doenças. Globo Rural, ano 18, n. 212, p. 26-33, São Paulo, Editora Globo, 2003.

VARAGO, F. C. et al. Produção in vitro de embriões bovinos: estado da arte e perspectiva de uma técnica em constante evolução. Revista Brasileira de Reprodução Animal, v. 32, n. 2, p. 100-109, Belo Horizonte, 2008.

Mirlei Fachini Vicente Pereira - Doutor em Geografia pela Universidade Estadual Paulista - Professor do curso de Geografia da Universidade Federal de Uberlândia.

Recebido para publicação em agosto de 2012

Aceito para publicação em outubro de 2012 